\title{
ERRATUM
}

\section{Syndrome de mastication unilatérale dominante acquise}

\section{Acquired dominant unilateral mastication syndrome}

\section{Catalina CANALDA}

Traduit par Agnès CRUZEL

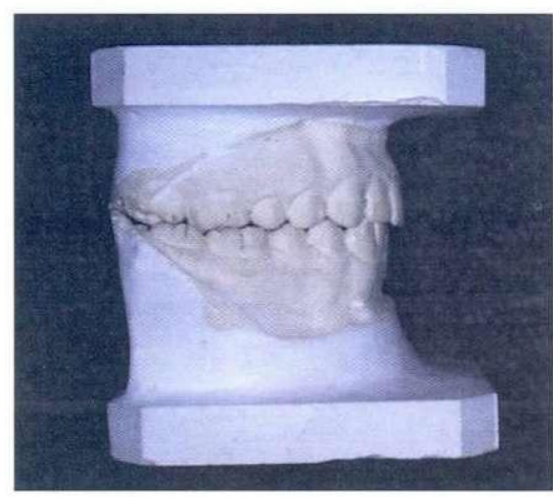

a

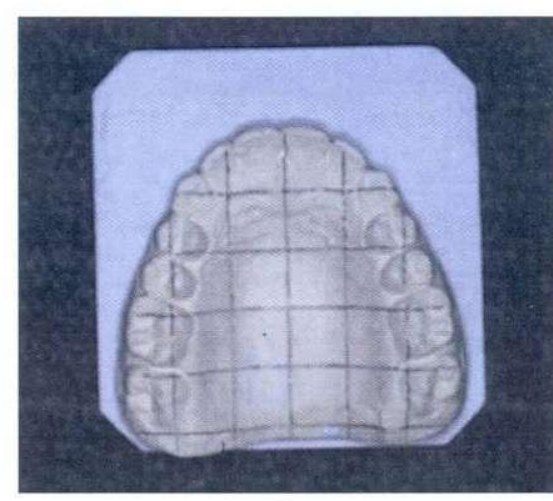

b

La Rédaction

Nous publions à nouveau, mais dans leur intégralité, les photos des moulages de cet article, paru dans le numéro 1 de 2002. En effet un recadrage trop important nuisant à leur lisibilité, la totalité du support n'apparaissait pas.

Nous prions les lecteurs de nous en excuser.

Figures $2 \mathrm{a}$ à / to $\mathrm{c}$

Laura: 12 ans.

Moulages gnathostatiques après traitement; noter la position du plan d'occlusion physiologique et la bonne symétrie antéropostérieure ainsi que transversale.

Laura: 12 years

Gnathostatic casts after treatment; please note the position of the physiological occlusal plane and good anteroposterior and transversal symmetry. 


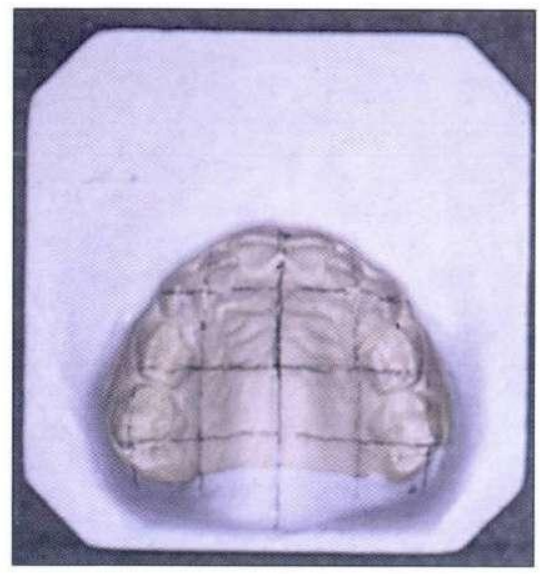

f

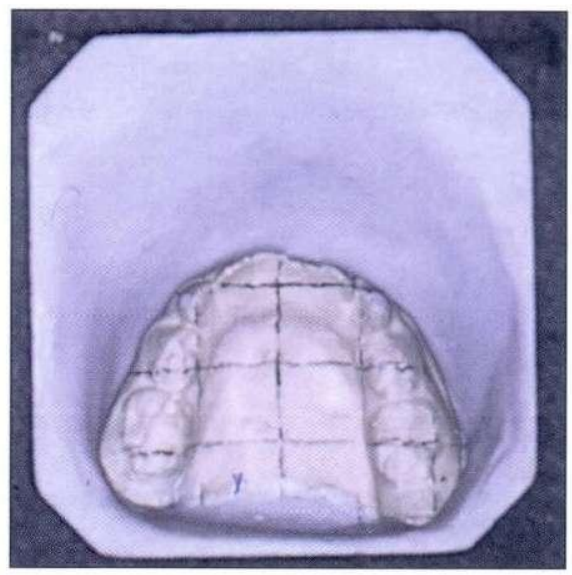

i

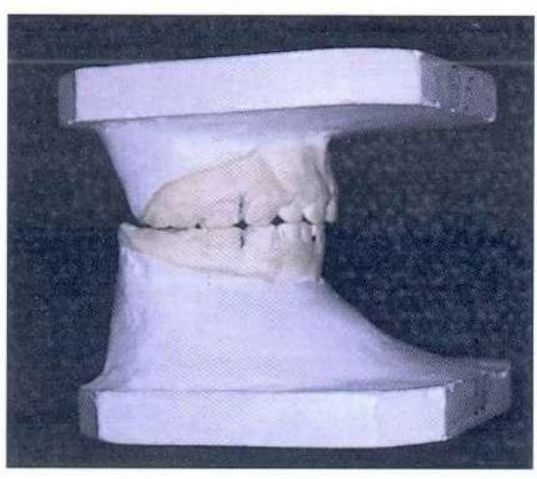

g

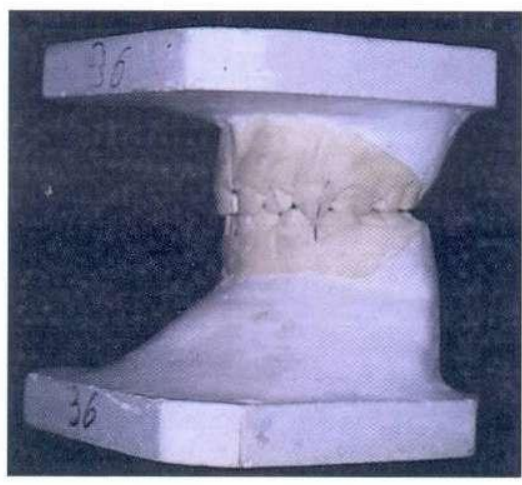

j

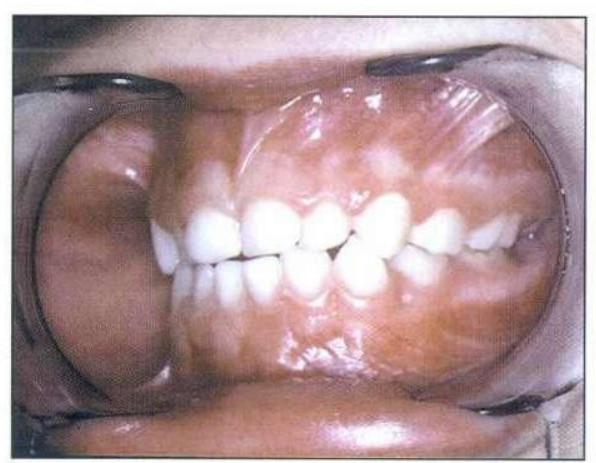

$\mathrm{h}$

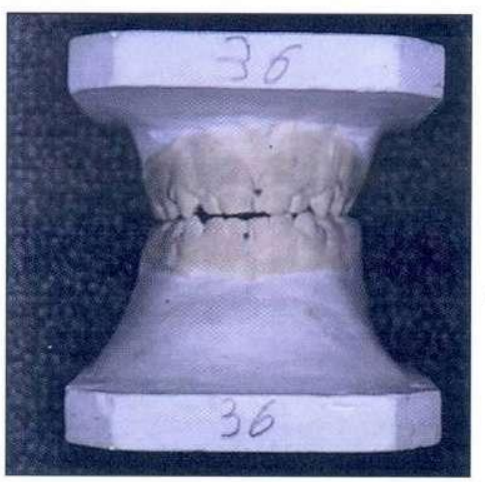

k

Figures $3 \mathrm{f}$ à $/$ to $\mathrm{k}$

$f$ : asymétrie entre les arcades transversale et sagittale; on note l'avancée et la position plus vestibulaire de l'hémi-arcade droite (côté habituellement mastiquant), qui conditionne la distoclusion mandibulaire de ce même côté).

$g$ : enregistrement gnathostatique; on note la classe II, «subdivision».

$h$ : occlusion gauche; on note la normoclusion canine du côté habituellement orbitant.

$i$ : asymétrie sagittale intra-arcade; on note l'avancée des dents de l'hémi-mandibule gauche (côté habituellement orbitant).

$j$ : enregistrement gnathostatique; on note la normoclusion gauche.

$k$ : moulages gnathostatiques, vus de face. On note la non-coïncidence des médianes interincisives.

$f$ : transverse and sagittal intra-arch asymmetry; one notes the projection and the more vestibular position of the right hemi-arch (usually mastication side), which conditions the mandibular distoclusion on this same side.

g: gnathostatic recording; one notes a Class II, "subdivision».

$h$ : left occlusion; one notes the canine normal occlusion on the usually non-working side.

i: sagittal intra-arch asymmetry; Please note the projection of the teeth of the left hemi-mandible (usually non-working side).

$j$ : gnathostatic recording; the left normal occlusion is noted.

$k$ : gnathostatic casts, front view. Please note the discrepancy of the interincisor midlines. 
d

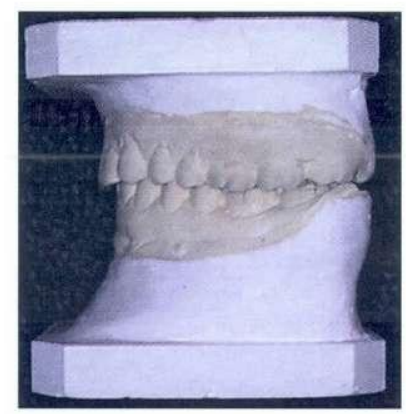

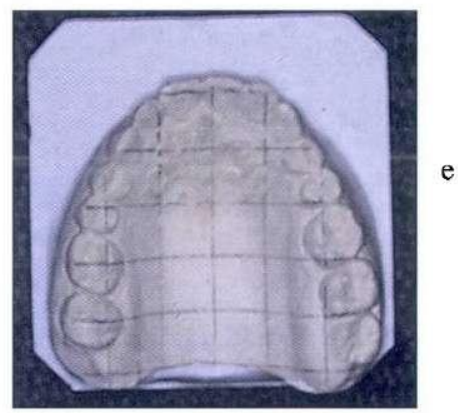
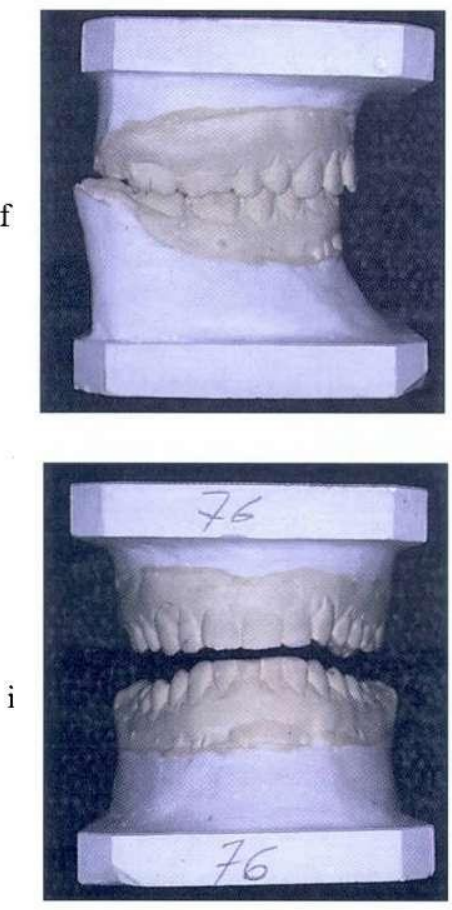

g
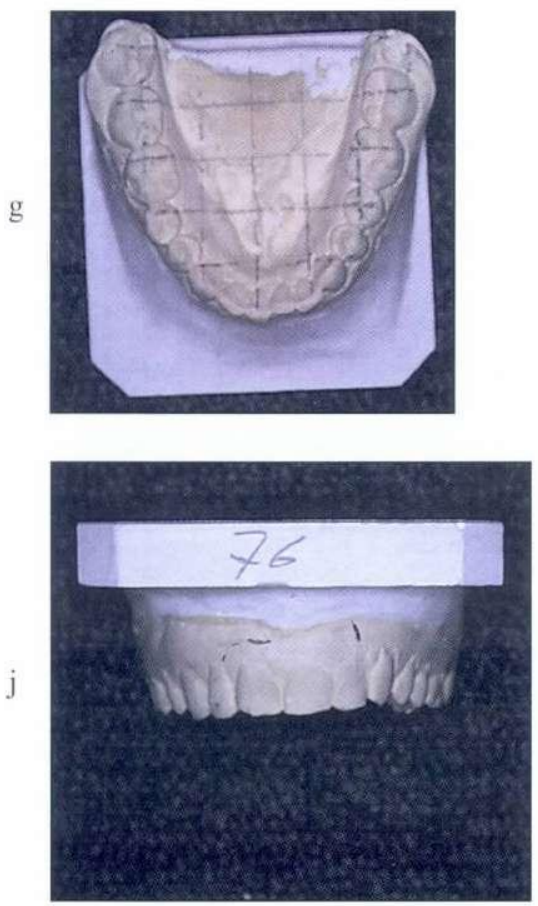

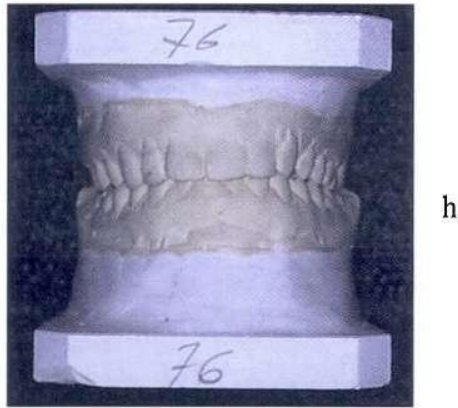

$\mathrm{h}$

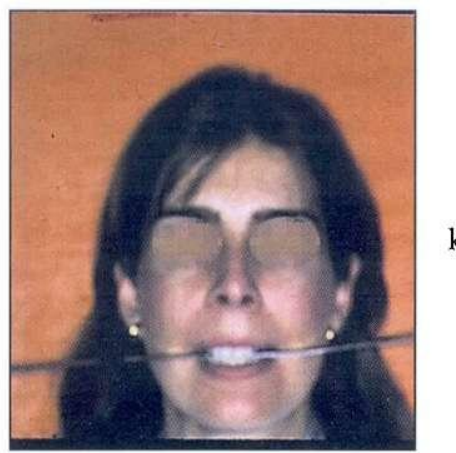

Figures $5 \mathrm{~d}$ à $/$ to $\mathrm{k}$

$d$ : distoclusion gauche secondaire à l'avancée de l'hémi-maxillaire ipsilatéral.

$e:$ observation des asymétries sagittales entre les arcades par rapport au plan frontal intertragial. Noter l'avancée de l'hémimaxillaire gauche, côté habituellement mastiquant.

$f$ : normoclusion molaire sagittale droite (classe I) en rapport avec l'avancée de l'hémi-mandibule ipsilatérale.

$g$ : observation des asymétries sagittales entre les arcades par rapport au plan horizontal parallèle au plan frontal intertragial. Noter l'avancée de l'hémi-mandibule droite (côté habituellement orbitant).

$h$ à $k$ : absence de parallélisme du plan occlusal avec le plan de Camper (matérialisé par la base du moulage supérieur). Convergence des deux bases vers le côté habituellement mastiquant (gauche).

$d$ : secondary left distoclusion secondary to the advancement of ipsilateral hemi-maxilla.

$e$ : observation of intra-arch sagittal asymmetries relative to the intertragial frontal plane. Please note the projection of the left hemi-maxilla, the side usually masticating.

$f$ : right sagittal normal molar occlusion (Class I) in connection with the projection of the ipsilateral hemi-mandible.

g: observation of intra-arch sagittal asymmetries relative to the horizontal plane parallel with the intertragial frontal plane. Please note the projection of the right hemi-mandible (usually non-working side).

$h$ to $k$ : absence of parallelism of the occlusal plane with Camper's plane (materialized by the base of the upper moulage). Convergence of the two bases towards the usually masticating side (left). 

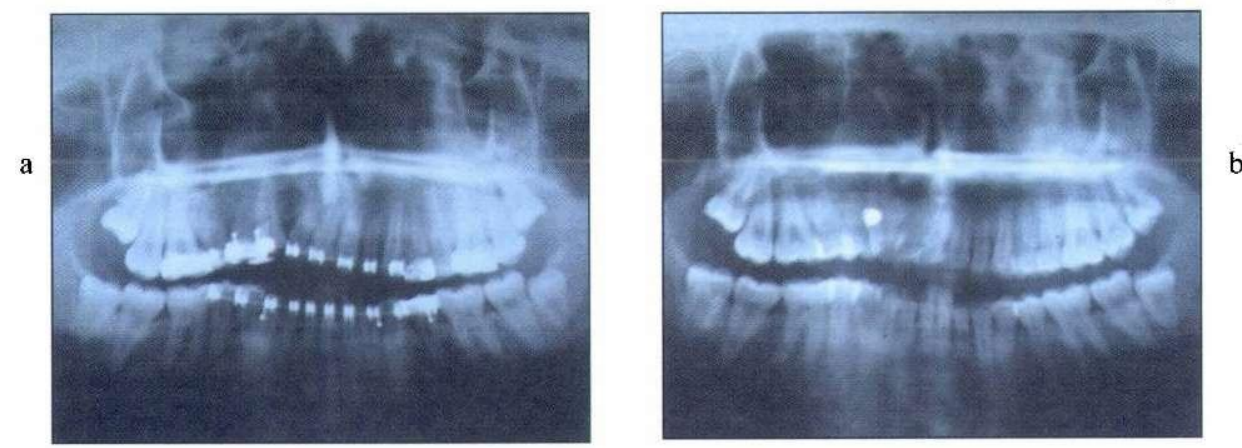

Figures $6 \mathrm{a}$ et $\mathrm{b}$

Alba: 21 ans / years.

$a$ : cliché panoramique, le jour de la première consultation; noter l'asymétrie occlusale et celle des A.T.M., ainsi que les troubles parodontaux et les résorptions radiculaires. Cette patiente porte un appareil multi-attache depuis sept ans.

$b$ : cliché panoramique effectué un an après la dépose des attaches et l'ajustement occlusal ; noter les différences de forme des condyles et des pentes condyliennes.

a: panoramic photograph, the day of the first consultation; please note the occlusal asymmetry and that of the TMJs., as well as the periodontal disorders and the radicular resorptions. This patient has been wearing a multi-bracket appliance for seven years.

$b$ : panoramic photograph taken one year after the removal of the attachments and occlusal adjustment; please note the differences in shape of the condyles and the condylar slopes.
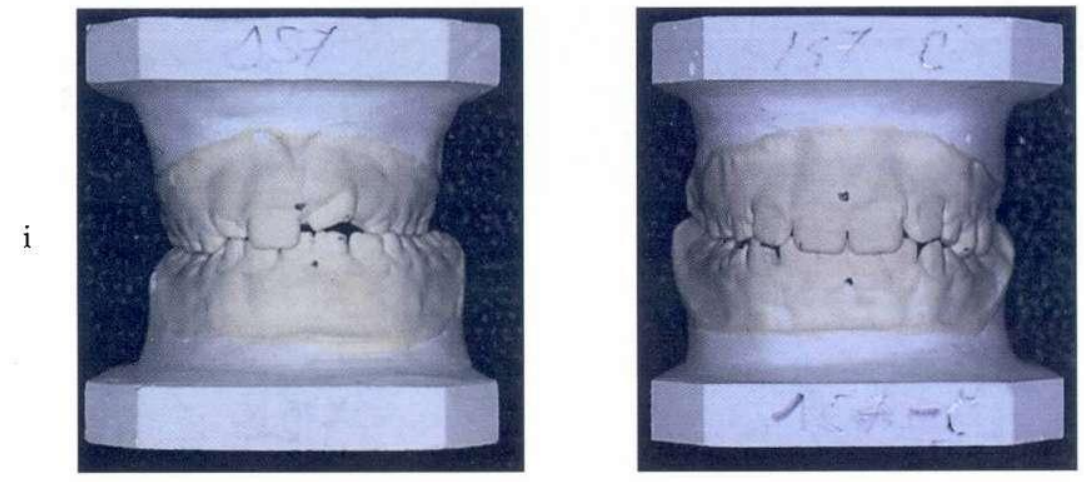

\section{$\mathrm{j}$}

Figures $7 \mathrm{a}$ à $\mathrm{j}$

Cas traité / Case treated

$i$ et $j$ : enregistrement gnathostatique avant et après traitement, mettant en évidence le développement des arcades et les modifications occlusales. Occlusion en relation centrée et occlusion fonctionnelle sont devenues une seule et même occlusion; en d'autres termes, l'occlusion fonctionnelle coïncide avec la relation centrée des condyles.

$i$ and $j:$ gnathostatic recording before and after treatment, highlighting the development of the arches and the occlusal alterations. Occlusion in centric relation and functional occlusion have become one and the same occlusion; in other words, functional occlusion coincides with the centric relation of the condyles. 